\title{
CONTROL OF LASIODIPLODIA THEOBROMAE ON AVOCADO IN EGYPT
}

\author{
M.A. Radwan and M.S.S. Hassan \\ Plant Pathol. Res. Inst., ARC, Giza, Egypt
}

Received: Oct. 27, 2016

Accepted: Nov. 1, 2016

\begin{abstract}
This study was performed during 2015-2016 seasons to identify fungal species associated with dieback, grafting failure process during vegetative propagation in commercial nursery and stem-end rot of avocado (Persea americana Mill.). Lasiodiplodia theobromae (syn. Botryodiplodia theobromae, Diplodia natalensis) was the most pathogenic as well as the most frequently isolated fungi whereas, the other isolated fungi (Alternaria solani, Fusarium moniliforme, F. solani, Aspergillus niger and Rhizopus stolonifer) were negligible. Hass and Fuerte were the most susceptible cultivars to dieback and stem-end rot diseases, followed by Eitinger, Duke and Reed, while Bekon and Benkerton recorded the lowest percentages of infection. Hass and Fuerte were susceptible to grafting failure process. All tested fungicides suppressed completely the avocado dieback infection when shoots were sprayed at the same time of inoculation with L. theobromae, followed by 7 days pre inoculation. On the other hand, spraying the avocado shoots 7 days post inoculation with L. theobromae was the least effective treatment in controlling the disease under greenhouse conditions. Dipping the scions in the tested fungicides before dipping it in spore suspensions of $L$. theobromae during grafting increased the percentage of success of grafted seedlings. Dipping avocado fruit after harvest in the tested fungicides before placing mycelial agar discs (5 $\mathrm{mm}$ diameter) of $L$. theobromae into a hole on the pedicel (stem) that was made with a 5-mm-diameter cork borer reduced the infection of stem-end rot. Generally, KemaZed, Amistar Top,Topsin M70 and Occidor were the most effective in controlling the avocado three diseases. This study confirms that stem-end rot and failure grafting followed by dieback of avocado can be initiated by fungus causing branch dieback and stresses the importance of controlling branch dieback.
\end{abstract}

Key words: Avocado, cultivars, dieback, grafting failure process, stem-end rot, Lasiodiplodia theobromae, fungicides.

\section{INTRODUCTION}

There are 57 avocado (Persea americana Mill.) producing countries in the world. The main producing countries in the world are Mexico, U.S.A, Colombia and Indonesia, with $36.8 \%$ of the world production in Mexico. The land that is currently destined for the growing of avocado totals 348,769 ha, producing $3,583,226$ tons a year (FAO, 2013). The avocado area is still small in Egypt, although, it was stated that avocado was introduced into Egypt between 1870 and 1880 as a botanical specimen (Milad, 1936). Old trees are very scarce in Egypt and nobody appreciated their existence. In late years, El-Qanater El-Khairia Horticultural
Research Station made fresh production of avocado commercial cultivars including Hass, Fuerte, Duke and others. The nutritional and medicinal uses of avocado have been confirmed through numerous studies. ( Elosaily, 2015 ) in Egypt, reported that avocado fruit and its pericarp fixed oil are usually considered as efficient components of healthy antioxidant diets. Essential oils of all cultivars showed good antimicrobial activities against Streptococcus mutans and Salmonella typhimurium (IC50 values, $0.4-20 \mathrm{uL} / \mathrm{mL}$ ). The mesocarp was found to contain higher amounts of vitamins $\mathrm{A}, \mathrm{C}$ and $\mathrm{E}$.

Dieback caused by Lasiodiplodia theobromae is the most important disease 
attacking Avocado. (Sutton ,1980) has adopted the name Lasiodiplodia theobromae. Lasiodiplodia theobromae (syn. Botryodiplodia theobromae, Diplodia natalensis) is the pycnidial state of Botryosphaeria rhodina, a pathogen that causes cankers and dieback in many woody and herbaceous species. Dieback symptoms appear at different stages of growth kills twig, shoot, branch and trunk wood causing great reduction in yield of diseased fruitful trees. It often attacks plants weakened by environmental stress or other pathogens and has caused death of many infected plants (Burgess et al., 2003).

Death of scions is a severe disease during propagation by grafting of avocado in El-Qanater El-Khairia Horticultural Research Station. Pathogenicity data showed that Lasiodiplodia theobromae is the causal agent of graft failure process of avocado. The two tested avocado cultivars Hass and Fuerte which inoculated onto the binding site with Lasiodiplodia theobromae were highly susceptible to infection with failure grafting seedlings and dieback. This may be the first study that provides isolation and pathogenicity data about a disease caused by $L$. theobromae during the avocado grafting process.

Stem-end rot of avocado fruit caused by Lasiodiplodia theobromae develops in the field, as well as after harvest during storage or shipment. The fungus enters through mechanically injured areas on the stem or skin. The fungus grows from the pedicel into a circular black lesion around the pedicel. Stem-end rot symptoms are dark spots with defined edges on the epidermis of the fruit that emanate from the stem end. The affected areas becomes soft and watery .

Lasiodiplodia theobromae was identified as branch cankers and dieback, dieback of avocado grafts during vegetative propagation in commercial nursery and stem-end rot of fruit on avocado trees in Egypt. In pathogenicity test, Lasiodiplodia theobromae has been associated with symptoms of dieback, necrosis at the binding site of grafting and stem- end rot. Hass cv. is the most popular and potential cultivar found to be highly susceptible to the three diseases. Lasiodiplodia theobromae has been associated with symptoms of dieback and necrosis at the binding site of grafting on cashew (Anacardium occidentale L.) propagative material (Freire et al., 2002) and grapevine (Aroca et al., 2008), as well as stem-end rot in guava (Psidium guajava L.) (Cardoso et al., 2002), dieback in citrus (Davis et al., 1987).The objective of this study was to evaluate the preventative ability of some commercial fungicides against fungus associated with avocado dieback, grafting failure process and stem-end rot.

\section{MATERIALS AND METHODS}

1- Disease severity of avocado dieback in orchards, percentage of the grafted failure seedlings in nursery and percentage of stem-end rot were evaluated from April to August 2015 and 2016 seasons in orchards, commercial nursery in El-Qanater El-Khairia Horticultural Research Station, Agricultural Research Centre.

\section{1- a- Disease severity of avocado dieback in orchards.}

Five symptomatic trees nearly uniform in size on seven avocado cultivars i.e. Hass, Fuerte, Duke, Reed, Eitinger ,Bekon and Benkerton were chosen randomly as replicates and sampled for branch dieback in order to calculate the disease severity (DS) according to the modified scale of (Barakat et al.,1990) as follows:

$$
\mathrm{DS}=\frac{\sum n \times V}{5 N} \times 100
$$

Where:

$\mathrm{n}=$ the number of diseased branches in each infected category.

$\mathrm{V}=$ Numerical value of the grade as follows:

$0=$ No infection (healthy).

$1=1.0-10 \%$ infection.

$2=10.1-25 \%$ infection.

$3=25.1-50 \%$ infection.

$4=50.1-75 \%$ infection. 


\section{Control of Lasiodiplodia theobromae on avocado in Egypt}

$5=75.1-100 \%$ infection

$\mathrm{N}=$ Total number of the branches inspected.

5 = Maximum disease severity grade.

\section{1- b- Percentage of the grafted failure seedlings in avocado nursery.}

In April 2015 and 2016, twenty five seedlings were chosen randomly as five replicates on two avocado cultivars, i.e. Hass and Fuerte to evaluate the grafted failure seedlings during adaptation in commercial nursery. Seedlings were grafted during February. Data were evaluated after 45 days from grafting.

\section{1- c- Percentage of stem-end rot in avocado fruit.}

In August 2015 and 2016 five symptomatic avocado trees nearly uniform in size were chosen randomly as replicates on seven avocado cultivars, i e. Hass, Fuerte , Duke , Reed, Eitinger, Bekon and Benkerton to investigate the percentage of stem-end rot .

\section{2-Isolation and identification of the associated fungi.}

Isolations were made from symptomatic material of diseased avocado collected from tip dieback of branches, grafted plants with scion dieback symptoms and diseased fruits. Samples were washed thoroughly with tap water then small pieces $(4-5 \mathrm{~mm})$ of tissue were taken from the margin between necrotic and apparently healthy tissue sterilized by dipping in (0.1\%) sodium hypochlorite for $3 \mathrm{~min}$., followed by rinsed several times in sterilized distilled water and dried between two pieces of sterilized filter paper and placed in petri dishes with potato dextrose agar culture medium (PDA). The dishes were incubated at $25^{\circ} \mathrm{C}$ for seven days. Hyphal tip and single spore techniques were used to purify the associated organism on PDA slants. Most frequent fungal colonies were purified and transferred to new petri dishes with PDA. Fungal isolates were grown onto (PDA) plates or slant and maintained at $5^{\circ} \mathrm{C}$ in a refrigerator for further studies. Stock cultures were routinely sub-cultured on fresh slant or plates every 6-8 weeks. Pure culture of the isolated fungi was identified (through culture characteristic and microscopic observation.

\section{3- Pathogenicity test. a- Pathogenicity test on branches.}

The pathogenic capability of the isolated fungi $L$. theobromae, A. solani, Fusarium moniliforme, F. solani, A. niger were done in Plant Pathology Greenhouse by using wooden toothpicks. Wooden toothpicks were autoclaved for 20 minutes, at $121^{\circ} \mathrm{C}$, and transferred occasionally as triangle around the inoculum disk of the isolated fungi on PDA plates. After incubation for one week, inoculated toothpick were removed and inserted into avocado green shoots (for $3-5$ $\mathrm{mm}$ depth). Twenty seedlings two-year old were used as four replicates. The same number of avocado seedlings was inoculated with only autoclaved toothpicks (un- inoculated) and served as control. Seedlings were incubated at normal temperature, dieback and/or the average length of necrotic $(\mathrm{mm})$ of each inoculated site was measured and data was recorded. Koch's postulates were confirmed by reisolation of the original pathogen from artificially inoculated shoots (Swart et al., 2003).

\section{b-Pathogenicity test during grafting.}

The operation conducted in this section was according to (Gaser, 2007) with minor modification .The inoculum for the pathogenicity tests for scions infection were prepared by adding $10 \mathrm{~mL}$ of sterile distilled water into $(\varnothing 9 \mathrm{~cm})$ sterilized petri dishes containing PDA medium and pure cultures of each fungus alone and scooping with a heat sterilized spatula to dislodge the conidia. The conidia suspension was filtered through an 8 layer cheese cloth. The concentration of conidia suspension for each isolate was adjusted to $1 \times 10^{6}$ conidia $/ \mathrm{mL}$ using a haemocytometer. A surfactant (Tween 20) was added to the conidia suspensions to 
give a more uniform suspension of spores that will spread more evenly over the plant surface. Before grafting, rootstocks were disbudded with a sharp knife, with the exception of the bottom buds un-removed. Grafting was done in February. Scions of avocado Hass and Fuerte cvs. wood was cut $12 \mathrm{~cm}$ long. Scions and rootstocks were immersed on the spore suspensions of each fungus for 20 minutes before joined. Each treatment contains four replicates and each replicate consists of five grafted seedlings. The same number of scions from each cultivar were dipped in the sterile distilled water and served as control. The rootstocks and scions were joined together and tying with poly-ethylene. \%Seedlings with failure grafting (scions breakdown and collapse followed by dieback) were calculated after 45 days from grafting.

\section{c- Pathogenicity test on fruit.}

For each isolate, twenty Hass fruit as four replicates freshly harvested in August by clipping were surface disinfected by dipping into a $(0.1 \%)$ sodium hypochlorite solution for $1 \mathrm{~min}$, rinsed with water, and allowed to air-dry. Mycelial agar discs ( $5 \mathrm{~mm}$ diameter) from the edge of actively growing cultures were placed into a hole on the pedicel (stem) that was made with a 5-mm-diameter cork borer. After 15 days, fruit were examined and \% disease incidence and \% disease severity were calculated. Small pieces of the flesh removed from the margin of the rot fruits were placed on PDA. Fungal colonies were compared morphologically to those of isolates used in the inoculations (Smith et al., 2012).

\section{Disease control.}

I- Effect of some fungicides on dieback of avocado seedlings.

Under greenhouse in 2015 and 2016 seasons, seven fungicides were used in this experiment namely Kemazed (carbendazim), kocide 2000 (copper hydroxide), Amistar Top (Difenoconazole + Azoxystrobin ),Topsin M70 (Thiophanate methyl), Antracol (dithiocarbamate), Occidor (benzimidazol) and Copprotech (copper oxychloride) with recommended commercial doses were evaluated to control avocado seedlings dieback. Sterilized atomizer filled with $500 \mathrm{~mL}$ of each tested fungicides. Avocado seedlings, two years' old (Hass cv.) were inoculated by using toothpick with $L$. theobromae as described in pathogenicity test. Twenty seedlings were used as 4 replicates for each treatment. Sprayed with tested treatment were done at the same time and pre or post 7 days of inoculation. 20 seedlings were sprayed with distilled water and served as control. Average length of necrotic dieback infection $(\mathrm{mm})$ of inoculated seedlings was calculated after 15, 21, 35 and 45 days from inoculation.

\section{II- Efficiency of some fungicides on the percentage of succeeded avocado grafted seedlings.}

In February 2015 and 2016, scions were chosen healthy in uniform $(1 \mathrm{~cm}$ thick and $12 \mathrm{~cm}$ tall) from Hass trees (the most susceptible cultivar), (around 20 years). Under greenhouse, twenty avocado scions of Hass cultivar for each treatment as four replicates were prepared to grafting on the same number of rootstocks. Immediately before pathogen inoculation, scions were dipped in one of each seven tested fungicides for one minute and left to airdrying for one minute. Scions were artificially inoculated with dipping separately in the spore suspensions of $L$. theobromae for 5 seconds. Twenty avocado scions were inoculated with tested pathogenic fungus, then grafted on the same number of rootstocks without any treatments where served as control .Both scions and rootstock were wrapped with polyethylene strips and kept under control for adaptation. The results as the percentage of grafting successes were recorded after 45 days from grafting. The efficiency of each treatment was calculated as follows: 
$\%$ Efficiency $=\frac{A-B}{A} \times 100$

Where:

$A=$ number of inoculated seedlings (control).

$\mathrm{B}=$ number of inoculated and treated seedlings (treatment).

\section{III- Effect of some fungicides on \% stem-end rot of avocado fruit.}

In August 2015 and 2016 seasons, post harvest dipping trials were carried out on Hass fruit to determine the effect of seven fungicides on the incidence of stem-end rot, compared to fruit left untreated or dipped in water. Twenty Hass fruit as four replicates per treatment were surface disinfected by dipping into a $(0.1 \%)$ sodium hypochlorite solution for $1 \mathrm{~min}$, rinsed with water, and allowed to air-dry. Mycelial agar discs $(5 \mathrm{~mm}$ diameter) from the edge of actively growing cultures of $L$. theobromae were placed into a hole on the pedicel (stem) that was made with a 5-mm-diameter cork borer. The following day, dipping treatments on the tested fungicides were done. The same number had been left untreated or treated with water only as control treatment .Once fruit had been dipped they were air dried and then re-packed into fruit boxes before been moved to a controlled environment ripening room set to $25^{\circ} \mathrm{C}$ and $80 \%$ relative humidity. After 12 days, fruit were examined and \%disease incidence was calculated (Smith et al., 2012).

\section{Statistical analysis:}

The experiment was arranged in a randomized complete blocks design and the obtained data were subjected to analysis of variance and significant differences among means according to Snedecor and Cochran (1984). In addition significant differences among means were distinguished according to the Duncan multiple test range.

\section{RESULTS AND DISCUSSION 1- Symptoms on trees in groves and on seedlings in nursery.}

The dieback disease on branches is characterized by drying of twigs and branches followed by complete defoliation، which gives the tree an appearance of scorching by fire. Tip die back disease occurs on the branches/ trunk of infected trees that start drying slowly at first and suddenly branches become completely dried /killed resulting gummy substance oozes out or remains hanging on the tree Fig. 1( a \& b). Avocado branch canker has long been known as Dothiorella canker because the pathogen most often isolated was known as Dothiorella gregaria Sacc. (teleomorph Botryosphaeria ribis) (Halma, and Zentmyer, 1953). Symptoms of avocado branch canker can occur on twigs, branches, or trunks. Canker infections are initiated by spores entering the host plants through fresh wounds such as pruning wounds, mechanical injuries, or injuries resulting from sunburn or frost damage (McDonald and Eskalen, 2011).Cankers on avocado may exude brownish red or reddish sap that dries to form a whitish-beige powder. The bark and xylem under the canker is killed and turns red-brown to brown. In older cankers, the dead bark can be easily removed, and if the xylem is colonized, leaves quickly turn brown but remain attached Fig. 1 (c). This may lead to the collapse of branches or entire trees. Canker infections become severe following stress caused by drought, flooding, insect attack, nutrient deficiencies, or any other factor that weakens the tree (Menge and Ploetz, 2003).

Dieback appeared in recently grafted plants, wilting and death of apical bud followed by dieback, gradual drying and cracking of the bark from the apex and moving down toward the base of the scion, developed 25 day after grafting. The union of the graft presented longitudinal extended necrosis. The vascular tissue of diseased scions showed hard texture (mummification of xylem and cortex) with a dark gray to black necrosis. When this happens, the flow of nutrients from the rootstock to the top growth (scion) becomes limited or stops completely and the top growth will gradually or suddenly deteriorate. Thirty days after 
grafting, abundant light gray mycelial growth was observed covering most of the scion and the graft union Fig. 1 ( $f \& g$ ).

Decay from stem-end rot begins as slight shrivelling around the stem button. Fungal mycelium is often visible on fruit if the button is removed. Conspicuous dark decay with a well-defined margin develops at the stem end. As fruit ripens, decay spreads and rots the entire fruit, which becomes dark and shrivelled. Depending on the causal organisms, flesh may be watery and soft, or initially dry and corky, becoming watery later as secondary organisms colonize tissue Fig. 1 (c, d \& e). Stem-end rot of avocado has been reported from all major production areas worldwide (Menge and Ploetz, 2003). (Johnson et al., 1991) suggested that stemend rot pathogens are endophytes (fungi growing inside the vascular system), living in the stems, branches and pedicels of the avocado canopy, which grow into the fruits to initiate the stem-end rots. In commercial avocado production, stem-end rot mostly occurs during transit, in the packinghouse, and during or after marketing (Twizeyimana et al., 2013). Stem-end rot are generally a relatively minor problem of avocados in California due to low relative humidity and rainfall during much of the growing season and harvest time (Faber et al., 2008.). (Aaron et al., 2006) reported that Stem-end rot is a post harvest disease that occasionally causes losses under suboptimal storage conditions. Fruit rot starts on the stem end and generally initiates as the fruit ripens or after harvest. Small, purplish-brown spots appear and can enlarge to involve the entire fruit surface. The pathogen invades the flesh causing tissue discoloration, degradation, and offensive odors, thus compromising the quality of the fruit.

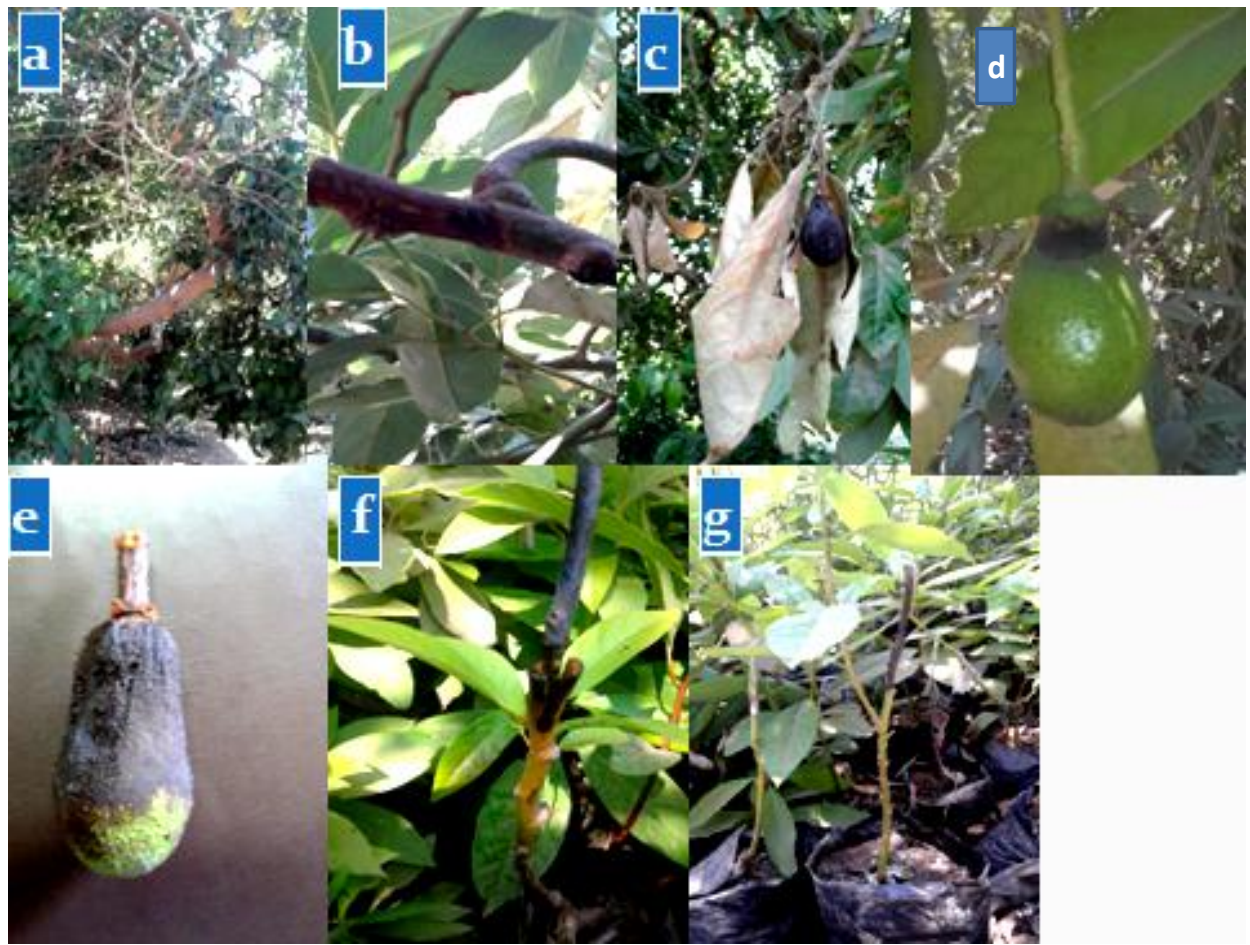

Figure1. (a \& b) avocado branches showed naturally typical dieback symptoms. (c) dieback appeared in shoot and fruit.( $d \&$ e) stem-end rot appeared on fruit in the field, small purplish-brown spots appear and can enlarge to involve the entire fruit surface. The spots gradually enlarge until much of the surface may be involved. (f) Natural dead scion after grafting. (g) Dieback appeared in the rootstock after grafting failure. 


\section{2- \%Disease severity of avocado dieback in orchards, \%grafted failure seedlings in nursery and \%stem-end rot.}

Dieback disease, failure in grafted seedlings in nursery and stem-end rot were found in all examined cultivars during the two successive growing seasons 2015 and 2016 (Table1). The results show significantly differences in disease severity percentage between avocado cultivars. Hass and Fuerte cvs. were the most susceptible cultivars which recorded the highest percentage of $\%$ disease severity and \%stem-end rot, followed by Eitinger, Duke and Reed, while Bekon and Benkerton cultivars recorded the lowest percentage of infection. The disease symptoms of failure in grafting and occurring dieback in seedlings were observed in the two examined cultivars. In this respect, Hass $\mathrm{cv}$. was the most susceptible one which recorded (32.00 and 28.00) \%failure in grafted seedlings in the two successive seasons respectively, while Feurte cv. was the least susceptible which recorded $(28.00$ and 24.00 ) \%failure in grafted seedlings in the two successive seasons respectively. Generally, Hass cv. was the most susceptible cultivar for dieback disease, failure in grafted seedlings in nursery and stem-end rot while Benkerton was the least susceptible one. These data suggest that $L$. theobromae is a natural pathogen causing branches dieback during prune and causing grafting failure process when penetrates the vascular tissue through wounds or cuts made by the propagator or grafter. The fungus enters through mechanically injured areas on the stem or skin and grows from the pedicel into a circular black lesion around the pedicel. This coincides with (Fourie and Halleen, 2004 and Abo Rehab et al., 2013) who affirm that the infected scions and rootstocks are the source of inoculum of pathogens that cause diseases during the vegetative grapevine propagation. (Tovar et al., 2013) reported that dieback of mamey sapote (Pouteria sapota) grafts is the most important disease during vegetative propagation in commercial nurseries. L. theobromae was associated with this disease in $97 \%$ of necrotic rootstocks and scions samples from a nursery. ( Darvas and Kotze, 1981)reported that Fuerte fruit proved the most susceptible and Ryan the least.

Table 1: Natural infection of dieback, failure in grafted seedlings and stem-end rot during two successive seasons 2015 and 2016.

\begin{tabular}{|c|c|c|c|c|c|c|c|c|}
\hline \multirow{2}{*}{ Cultivars } & \multicolumn{2}{|c}{$\begin{array}{c}\text { \%Dieback disease } \\
\text { severity }\end{array}$} & \multicolumn{2}{c|}{$\begin{array}{c}\text { \% failure in grafted } \\
\text { seedlings }\end{array}$} & \multicolumn{2}{|c|}{$\%$ stem- end rot } & \multicolumn{2}{|c|}{ Mean } \\
\cline { 2 - 9 } & 2015 & 2016 & 2015 & 2016 & 2015 & 2016 & 2015 & 2016 \\
\hline Hass & $25.30 \mathrm{~A}$ & $23.96 \mathrm{~A}$ & $32.00 \mathrm{~A}$ & $28.00 \mathrm{~A}$ & $15.13 \mathrm{~A}$ & $12.23 \mathrm{~A}$ & 24.14 & 21.39 \\
\hline Fuerte & $22.74 \mathrm{~B}$ & $21.04 \mathrm{~B}$ & $28.00 \mathrm{~B}$ & $24.00 \mathrm{~B}$ & $13.14 \mathrm{~B}$ & $11.51 \mathrm{~B}$ & 21.29 & 18.85 \\
\hline Duke & $20.21 \mathrm{C}$ & $18.62 \mathrm{C}$ & - & - & $12.11 \mathrm{BC}$ & $10.40 \mathrm{BC}$ & 16.16 & 14.51 \\
\hline Reed & $17.52 \mathrm{D}$ & $16.26 \mathrm{D}$ & - & - & $11.94 \mathrm{BC}$ & $9.91 \mathrm{C}$ & 14.73 & 13.08 \\
\hline Eitinger & $21.12 \mathrm{BC}$ & $20.22 \mathrm{~B}$ & - & - & $12.86 \mathrm{~B}$ & $10.75 \mathrm{BC}$ & 16.99 & 15.48 \\
\hline Bekon & $15.52 \mathrm{E}$ & $13.03 \mathrm{E}$ & - & - & $10.85 \mathrm{C}$ & $8.32 \mathrm{D}$ & 13.18 & 10.67 \\
\hline Benkerton & $12.27 \mathrm{~F}$ & $11.27 \mathrm{~F}$ & - & - & $8.44 \mathrm{D}$ & $6.38 \mathrm{E}$ & 10.35 & 8.82 \\
\hline
\end{tabular}

$=$ not detected 


\section{3- Isolation.}

Isolation from infected branchs, seedlings and fruits yielded six species representing five fungal genera. $L$. theobromae recorded the highest frequency percentages in two seasons, followed by $F$. moniliforme while the other pathogens $A$.solani, $F$. solani, $A$. niger and Rhizopus stolonifer, respectively recorded low percentages of frequency (Table 2). Diseases caused by species of Botryosphaeriaceae have been reported in California from avocado (Horne,1932 and McDonald and Eskalen, 2011), almond (English et al., 1996), grapevine (UrbezTorres, 2006), pistachio (Michailides, 1991) and in México from mamey sapote (Tovar et al., 2013). In Egypt from grapevine (Abo Rehab et al., 2013) reported that Phomopsis viticola was the most frequent pathogen isolated from grafted failure seedlings, followed by Lasiodiplodia theobromae. Whereas, the other isolated fungi (Phoma sp., Fusarium solani and Alternaria solani) were negligible. Lasiodiplodia theobromae generally recovered in greater numbers from stem-end rot of avocado fruit than other fungi and are often associated with severe rots (Rowell, 1983). Stem-end rot pathogens are present in living and dead branches, twigs, leaves, and in living pedicels (Hartill and Everett 2002).

\section{4- Pathogenicity test.}

a- Pathogenicity test on branches.

Data in (Table 3 and Fig. 2) show that, $L$. theobromae was able to induce avocado dieback after 45 days from inoculation. Necrotic length $(\mathrm{mm})$ was increased by increasing incubation period from 15-35 days before appearance typical dieback symptoms after 45 days from inoculation, while $F$. moniliforme and $F$. Solani were able to exhibit avocado twigs necrotic (necrosis) only, but a typical dieback disease symptoms did not appear. However, $A$. solani and Aspergillus niger were not able to exhibit necrosis or dieback symptoms in artificially inoculated avocado twigs. Observed symptoms in inoculated seedlings included brown, necrotic bark lesions around the inoculation sites extending upwards and downwards, leading to wilting and drying of the apical as well as the terminal leaves. Cracking of the stem cortex was observed and fungal structures (stromatic pycnidia and mycelium) developed on the necrotic lesions around the inoculation sites. Under the outer cortex, necrotic xylem vessels and brown discoloration extended along the length of the stems (Fig. 2c).These results are in agreement with( Abd El Aziz et al., 2010) who reported that mango seedlings inoculated with Lasiodiplodia theobromae alone showed typical symptoms of the disease. No symptoms were observed on plants inoculated with other fungi. Lasiodiplodia theobromae caused dieback while the remaining pathogenic fungi caused necrotic area beginning from the site of artificial inoculation and vary in the necrotic parts.

Table 2: Fungi and their frequency (\%) isolated from avocado branches, grafted seedlings and fruits naturally infected with dieback disease.

\begin{tabular}{|l|c|c|c|c|c|c|c|c|}
\hline \multirow{3}{*}{ Isolated fungi } & \multicolumn{7}{|c|}{ Frequency (\%) } \\
\cline { 2 - 10 } & \multicolumn{3}{|c|}{2015} & \multicolumn{3}{c|}{2016} & \multicolumn{2}{c|}{ Mean } \\
\cline { 2 - 10 } & Branches & $\begin{array}{c}\text { Grafted } \\
\text { seedlings }\end{array}$ & Fruits & Branches & $\begin{array}{c}\text { Grafted } \\
\text { seedlings }\end{array}$ & Fruits & 2015 & 2016 \\
\hline L. theobromae & 58.34 & 51.39 & 56.94 & 55.56 & 54.17 & 55.56 & 55.56 & 55.09 \\
\hline A. solani & 8.33 & 12.50 & 16.66 & 11.11 & 13.89 & 15.28 & 12.50 & 13.43 \\
\hline F. moniliforme & 22.22 & 25.00 & 15.28 & 18.05 & 19.44 & 13.88 & 20.83 & 17.12 \\
\hline F. solani & 8.33 & 9.72 & 2.78 & 11.11 & 12.50 & 4.17 & 6.94 & 9.26 \\
\hline A. niger & 2.78 & 1.39 & 4.17 & 4.17 & - & 4.17 & 2.78 & 2.32 \\
\hline Rhizopus stolonifer & - & - & 4.17 & - & - & 6.94 & 1.39 & 2.78 \\
\hline
\end{tabular}

$-=$ not detected 


\section{Control of Lasiodiplodia theobromae on avocado in Egypt}

Table 3: Necrotic length around inculated stem and dieback ( $\mathrm{mm}$ ) on Hass cv. seedlings inoculated by the tested fungi.

\begin{tabular}{|c|c|c|c|c|c|c|c|c|}
\hline \multirow[b]{3}{*}{ Isolated fungi } & \multicolumn{8}{|c|}{ Necrotic length and dieback $(\mathrm{mm})$ after inoculation days } \\
\hline & \multicolumn{2}{|c|}{15} & \multicolumn{2}{|c|}{21} & \multicolumn{2}{|c|}{35} & \multicolumn{2}{|c|}{45} \\
\hline & 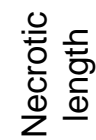 & 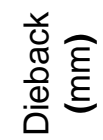 & 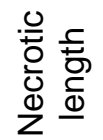 & 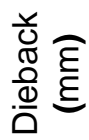 & 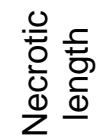 & 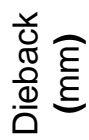 & 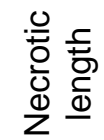 & 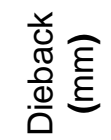 \\
\hline L.theobromae & 10.00 & 0.00 & 24.75 & 0.00 & 60.50 & 0.00 & 90.25 & 111.00 \\
\hline A. solani & 0.00 & 0.00 & 0.0 & 0.00 & 0.00 & 0.00 & 0.00 & 0.00 \\
\hline F. moniliforme & 3.50 & 0.00 & 5.25 & 0.00 & 12.50 & 0.00 & 20.25 & 0.00 \\
\hline \begin{tabular}{|l} 
F. solani \\
\end{tabular} & 2.50 & 0.00 & 2.75 & 0.00 & 5.00 & 0.00 & 8.00 & 0.00 \\
\hline A. niger & 0.00 & 0.00 & 0.00 & 0.00 & 0.00 & 0.00 & 0.00 & 0.00 \\
\hline
\end{tabular}

LSD at $0.5 \%$ for:

Necrotic $(\mathrm{N})=0.490$

$\mathrm{N} \times \mathrm{F}=0.422$

$\mathrm{N} \times \mathrm{F} \times \mathrm{D}=1.549$
Fungi $(F)=0.548$

$\mathrm{N} \times \mathrm{D}=0.693$
(Days) $D=1.096$

$\mathrm{F} \times \mathrm{D}=0.775$

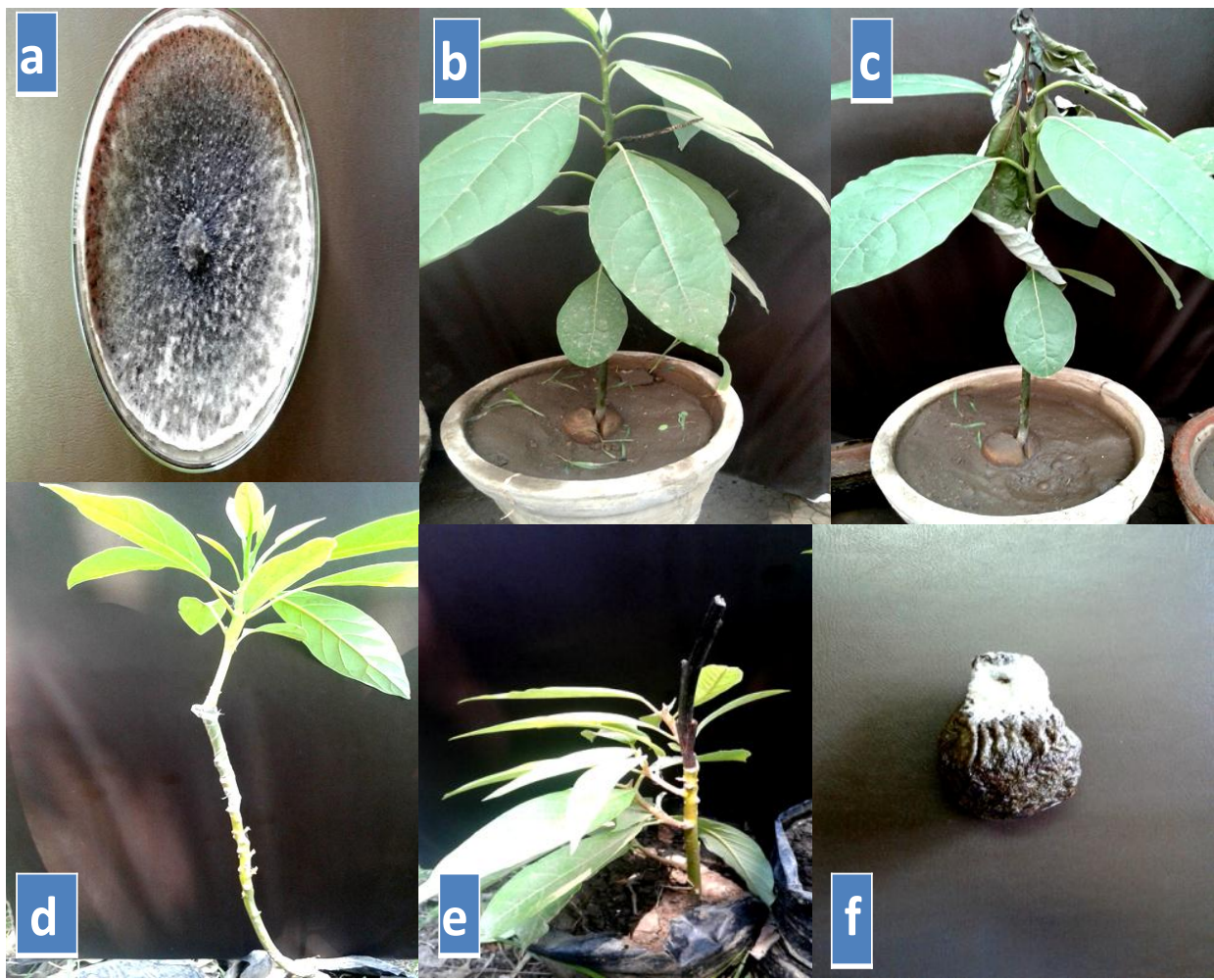

Figure 2. a - Morphology of isolated fungus $L$. theobromae on PDA culture colonies were initially white, soon becoming black and fast-spreading with immersed and superficial, branched, septate mycelium. Shiny black pycnidia were produced on the surface.

b-inoculated avocado seedlings using tooth pick method.

c- Typical dieback symptoms of avocado seedling after 45 days from stem inoculation showed wilting and death of leaves in apical region of an inoculated plant.

e- Failure grafted seedlings at the beginning of adaptation period compared with control (d).

f- Inoculated fruit with $L$. theobromae mycelial agar discs (5 $\mathrm{mm}$ diameter) from the edge of actively growing cultures. 


\section{b- Pathogenicity test during grafting:}

Pathogenicity test of two avocado cultivars during grafting showed that Hass and Fuerte cultivars seedlings which inoculated with $L$. theobromae were collapse and breakdown and recorded $100 \%$ and $90 \%$ ) failure grafting seedlings, respectively and recorded $(110.00$ and $100.75 \mathrm{~mm})$ dieback respectively (Tabel 4). All failure seedlings exhibited distinguished symptoms as grafted area is turned into a brown to black and oblique separation occurred between scion and rootstock. Fungal growth was seen at the grafting area. Necrosis appeared in recently grafted seedlings. Wilting and death of apical bud followed by dieback, gradual drying and cracking of the bark from the apex and moving down toward the base of the scion, developed $15 \mathrm{~d}$ after grafting. Longitudinal extended necrosis was presented in local union of the grafting. The vascular tissue of diseased scions showed hard texture (mummification of xylem and cortex) with a dark gray to black necrosis. 30 days after grafting, abundant light gray mycelial growth was observed covering most of the scion and the graft union after that dieback appeared in seedlings (Fig 2 e) compared with control (Fig 2 d). While $F$. moniliforme and $F$. Solani were able to exhibit \% Seedlings with failure grafting, but they were not able to exhibit Seedlings with dieback (mm). However, A. solani and Aspergillus niger were not able to exhibit $\%$ Seedlings with failure grafting or dieback symptoms. Wilting symptoms in apical buds, dieback of scions, and abundant grayish mycelial growth at the graft union were observed at $45 \mathrm{~d}$ of the inoculated plants. Rapid dieback after inoculation of grafted plants was probably due to the fungus infection during the formation of new vascular tissue in the rootstock and the scion, and prior to lignifications, which facilitated the development of this pathogen. The deep and extensive cuts made in the scions for the purpose of propagation probably facilitated pathogen penetration to vascular tissue (Ploetz et al., 1996). Subimmersed and erumpent pycnidia were observed on the graft union area.These findings correlate with the symptoms reported in grafted plants infected with $L$. theobromae (Cardoso et al., 2002). Dieback of mamey sapote [Pouteria sapota ) grafts significantly reduces the success of grafting in Mexican nurseries .Pathogenicity and histopathological data showed that Lasiodiplodia theobromae is the causal agent of dieback of mamey sapote grafts (Tovar et al., 2013). This may be the first study that provides a better understanding of a disease caused by $L$. theobromae during the grafting process of avocado.

Table 4: pathogenicity test on two avocado cultivars during grafting.

\begin{tabular}{|c|c|c|c|c|}
\hline \multirow{2}{*}{ Cultivars } & \multicolumn{2}{|c|}{ Hass } & \multicolumn{2}{c|}{ Fuerte } \\
\hline & $\begin{array}{c}\text { \%Seedlings with } \\
\text { failure grafting }\end{array}$ & $\begin{array}{l}\text { Seedlings with } \\
\text { dieback (mm) }\end{array}$ & $\begin{array}{c}\text { \%Seedlings with } \\
\text { failure grafting }\end{array}$ & $\begin{array}{c}\text { Seedlings with } \\
\text { dieback(mm) }\end{array}$ \\
\hline L. theobromae & $100.00 \mathrm{~A}$ & $110.00 \mathrm{~A}$ & $90.00 \mathrm{~A}$ & $100.75 \mathrm{~A}$ \\
\hline A. solani & $0.00 \mathrm{D}$ & $0.00 \mathrm{~B}$ & $0.00 \mathrm{C}$ & $0.00 \mathrm{~B}$ \\
\hline F. moniliforme & $25.00 \mathrm{~B}$ & $0.00 \mathrm{~B}$ & $20.00 \mathrm{~B}$ & $0.00 \mathrm{~B}$ \\
\hline F. solani & $10.00 \mathrm{C}$ & $0.00 \mathrm{~B}$ & $5.00 \mathrm{C}$ & $0.00 \mathrm{~B}$ \\
\hline A. niger & 0.00D & 0.00B & $0.00 \mathrm{C}$ & $0.00 \mathrm{~B}$ \\
\hline
\end{tabular}




\section{C- Pathogenicity trial on fruit}

(Table 5) show that after 15 days, $L$. theobromae was able to induce (100 and $75 \%)$ disease incidence and $(56 \%$ and $42.25 \%$ ) disease severity on Hass and Benkerton cultivars, receptively .While $A$. solani, Rhizopus stolonifer and $A$. niger exhated $(15,10 \%, 10,10 \%$ and $10,5 \%)$ disease incidence and (6.25, $4.50 \%, 4.75,3.25 \%$ and $3,2.25 \%$ ) disease severity on Hass and Benkerton cultivars, receptively. However $F$. moniliforme and $F$. solani were not able to exhibit disease incidence and disease severity on Hass and Benkerton cultivars, receptively. Inoculations with $L$. theobromae only resulted in decay from stem begins as slight shriveling around the stem button. Fungal mycelium are often visible on fruit if the button is removed. Conspicuous dark decay with a well-defined margin develops at the stem end. As fruit ripens, decay spreads and rots the entire fruit, which becomes dark and shriveled. irregularly shaped, roughly circular black brown lesions appeared on the surface of the fruit (Fig 2 f).( Darvas and Kotze, 1981) reported that in tests on fruits of 4 cultivars Rhizopus stolonifer, Botryodiplodia theobromae and Colletotrichum gloeosporioides [Glomerella cingulata] were the most pathogenic of 9 stem-end rot isolates. In the United States, B. Dothidea was reported as the causal pathogen of stem-end rot (Menge and Ploetz, 2003). (McDonald and Eskalen, 2011) found that the majority of fungi that cause avocado tree branch cankers are the same as those that lead to stem-end rot.The present study proved that $L$. theobromae associated with avocado branch dieback, grafting failure seedlings and stem-end rot .

\section{5- Control. \\ I- Effect of some fungicides on dieback of avocado seedlings:}

Data in (Table 6) show that time of application markedly affected the efficiency of the fungicides. All tested fungicides were effective in controlling avocado dieback infection when shoots were sprayed at the same time of artificial inoculation with $L$. theobromae where the average of dieback infected areas were zero at all incubation periods which ranged between 15-45 days ,followed by sprayed 7 days pre artificial inoculation with $L$. theobromae. On the other hand, spraying the avocado shoots 7 days post inoculation with $L$. theobromae was the least effective treatment in controlling the disease under greenhouse conditions in the two succesive seasons. Data also show that, spraying pre 7 days from inoculation exhibited more suppression than spraying post 7 days from inoculation. Kemazed, Amistar Top and Topsin M70 proved to be the highly effective in reducing the Length of necrotic area (infected part $\mathrm{mm}$ ), followed by Occidor and Antracol while Kocide 2000 and Copprotech were the least effective ones.

Table 5: pathogenicity test of two avocado cultivars fruits.

\begin{tabular}{|c|c|c|c|c|}
\hline \multirow{2}{*}{ Cultivars } & \multicolumn{2}{|c|}{ Hass } & \multicolumn{2}{c|}{ Benkerton } \\
\cline { 2 - 5 } & $\begin{array}{c}\text { \%Disease } \\
\text { incidence }\end{array}$ & $\begin{array}{c}\text { Disease } \\
\text { \%severity }\end{array}$ & $\begin{array}{c}\text { \%Disease } \\
\text { incidence }\end{array}$ & \%Disease severity \\
\hline L. theobromae & $100.00 \mathrm{~A}$ & $56.00 \mathrm{~A}$ & $75.00 \mathrm{~A}$ & $42.25 \mathrm{~A}$ \\
\hline A. solani & $15.00 \mathrm{~B}$ & $6.25 \mathrm{~B}$ & $10.00 \mathrm{~B}$ & $4.50 \mathrm{~B}$ \\
\hline F. moniliforme & $0.00 \mathrm{D}$ & $0.00 \mathrm{D}$ & $0.00 \mathrm{D}$ & $0.00 \mathrm{D}$ \\
\hline F. solani & $0.00 \mathrm{D}$ & $0.00 \mathrm{D}$ & $0.00 \mathrm{D}$ & $0.00 \mathrm{D}$ \\
\hline A. niger & $10.00 \mathrm{C}$ & $3.00 \mathrm{C}$ & $5.00 \mathrm{C}$ & $2.25 \mathrm{C}$ \\
\hline Rhizopus stolonifer & $10.00 \mathrm{C}$ & $4.75 \mathrm{BC}$ & $10.00 \mathrm{~B}$ & $3.25 \mathrm{C}$ \\
\hline
\end{tabular}


Table 6: Effect of different fungicides on the length of infected parts $(\mathrm{mm})$ in Hass cv. inoculated with $L$. theobromae under greenhouse conditions.

\begin{tabular}{|c|c|c|c|c|c|c|c|c|c|c|c|c|c|}
\hline \multirow[t]{4}{*}{ 节 } & \multirow{3}{*}{$\begin{array}{l}00 \\
\frac{0}{0} \\
\frac{0}{0} \\
\frac{0}{9} \\
\frac{5}{4}\end{array}$} & \multicolumn{6}{|c|}{2015} & \multicolumn{6}{|c|}{2016} \\
\hline & & \multicolumn{12}{|c|}{ Length of necrotic area (infected part $\mathrm{mm}$ ) after inoculation days } \\
\hline & & 15 & 21 & 35 & 45 & Mean & \%reduction & 15 & 21 & 35 & 45 & Mean & \%reduction \\
\hline & Control & 10.00 & 24.75 & 60.50 & 90.25 & 46.37 & - & 10.50 & 25.50 & 64.25 & 93.0 & 48.31 & - \\
\hline \multirow{7}{*}{ 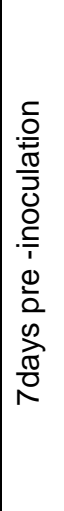 } & Kemazed & 2.00 & 4.50. & 7.00 & 8.25 & 5.43 & 88.28 & 2.00 & 5.25 & 7.25 & 9.50 & 6.00 & 87.58 \\
\hline & kocide 2000 & 6.00 & 9.50 & 11.50 & 14.00 & 10.25 & 77.90 & 5.50 & 9.00 & 11.75 & 14.00 & 10.00 & 79.30 \\
\hline & Amistar Top & 2.25 & 4.25 & 7.00 & 9.50 & 5.75 & 87.59 & 2.00 & 4.50 & 6.50 & 9.00 & 5.50 & 88.62 \\
\hline & Topsin M70 & 3.00 & 5.50 & 8.00 & 10.00 & 6.62 & 85.72 & 4.00 & 7.00 & 8.75 & 12.00 & 7.93 & 83.58 \\
\hline & Antracol & 4.00 & 6.25 & 10.50 & 12.75 & 8.37 & 81.94 & 5.75 & 9.25 & 11.00 & 13.00 & 9.75 & 79.82 \\
\hline & Occidor & 3.00 & 7.50 & 10.00 & 12.00 & 8.12 & 82.48 & 4.25 & 6.50 & 9.00 & 12.25 & 8.00 & 83.44 \\
\hline & Copprotech & 5.50 & 9.00 & 11.50 & 13.50 & 9.87 & 78.71 & 6.25 & 9.50 & 11.75 & 14.00 & 10.38 & 78.51 \\
\hline \multirow{7}{*}{ 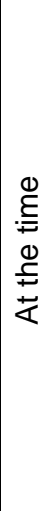 } & Kemazed & 0.00 & 0.00 & 0.00 & 0.00 & 0.00 & 100.00 & 0.00 & 0.00 & 0.00 & 0.00 & 0.00 & 100.00 \\
\hline & kocide 2000 & 0.00 & 0.00 & 0.00 & 0.00 & 0.00 & 100.00 & 0.00 & 0.00 & 0.00 & 0.00 & 0.00 & 100.00 \\
\hline & Amistar Top & 0.00 & 0.00 & 0.00 & 0.00 & 0.00 & 100.00 & 0.00 & 0.00 & 0.00 & 0.00 & 0.00 & 100.00 \\
\hline & Topsin M70 & 0.00 & 0.00 & 0.00 & 0.00 & 0.00 & 100.00 & 0.00 & 0.00 & 0.00 & 0.00 & 0.00 & 100.00 \\
\hline & Antracol & 0.00 & 0.00 & 0.00 & 0.00 & 0.00 & 100.00 & 0.00 & 0.00 & 0.00 & 0.00 & 0.00 & 100.00 \\
\hline & Occidor & 0.00 & 0.00 & 0.00 & 0.00 & 0.00 & 100.00 & 0.00 & 0.00 & 0.00 & 0.00 & 0.00 & 100.00 \\
\hline & Copprotech & 0.00 & 0.00 & 0.00 & 0.00 & 0.00 & 100.00 & 0.00 & 0.00 & 0.00 & 0.00 & 0.00 & 100.00 \\
\hline \multirow{7}{*}{ 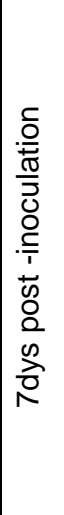 } & Kemazed & 5.75 & 9.25 & 11.50 & 14.00 & 10.12 & 78.17 & 6.25 & 10.25 & 11.75 & 14.00 & 10.56 & 78.14 \\
\hline & kocide 2000 & 6.75 & 12.75 & 15.75 & 19.25 & 13.62 & 70.62 & 11.00 & 13.25 & 16.00 & 20.50 & 15.18 & 68.57 \\
\hline & Amistar top & 6.25 & 9.75 & 11.75 & 14.00 & 10.43 & 77.50 & 7.25 & 11.25 & 12.50 & 15.00 & 11.50 & 76.19 \\
\hline & Topsin M70 & 7.00 & 9.50 & 13.50 & 16.50 & 11.62 & 74.94 & 7.75 & 12.25 & 14.25 & 16.50 & 12.56 & 74.01 \\
\hline & Antracol & 9.25 & 11.00 & 13.75 & 17.00 & 12.75 & 72.50 & 9.75 & 12.00 & 16.25 & 18.75 & 14.18 & 70.64 \\
\hline & Occidor & 7.75 & 9.50 & 14.00 & 16.75 & 12.00 & 74.12 & 9.00 & 12.25 & 15.0 & 16.50 & 13.18 & 72.72 \\
\hline & Copprotech & 7.00 & 13.00 & 16.25 & 20.00 & 14.06 & 69.67 & 11.50 & 13.75 & 16.75 & 20.75 & 15.68 & 67.54 \\
\hline
\end{tabular}

LSD at $0.5 \%$ for:

In 2015 :

Time $(T)=0.2642$

Days $(D)=0.4315$

$\mathrm{T} \times \mathrm{D}=0.7474$

$\mathrm{T} \times \mathrm{F} \times \mathrm{D}=1.9440$
Fungicides $(F)=0.3051$

$T \times F=0.5285$

$F \times D=0.8630$
Time $(T)=0.2617$ Days (D) $=0.4274$

$\mathrm{T} \times \mathrm{D}=0.7403$

$\mathrm{T} \times \mathrm{F} \times \mathrm{D}=1.9330$ in 2016 :

Fungicides $(F)=0.3022$

$\mathrm{T} \times \mathrm{F}=0.5234$

$F \times D=0.8548$ 


\section{II- Efficiency of some fungicides on the percentages of succeeded avocado grafted seedlings and stem-end rot.}

In 2015 and 2016 trials, dipping the scions of Hass cv. in each of the used fungicides suspensions before dipping it in spore suspensions of $L$. theobromae led to suppress spore formation of the pathogen during grafting and increased the percentage of success of grafted plants in all seedlings compared to control (untreated). Amistar Top, Topsin M70, Kemazed and Occidor were the most effective treatments for controlling grafting failure. Antracol and Copprotech exhibited moderate effect while kocide 2000 was the least effective fungicide (Table 7). The obtained results of in vivo trails could be discussed in light the findings of (Abo Rehab et al. 2013) who found that Topsin M 70\% and Kemazed gave the best results for controlling fungal pathogens cause grape graft failure.
Dipping avocado fruit after harvest in solutions containing the tested fungicides, compared to fruit left untreated or dipped in water reduced the infection of stem-end rot. Topsin M70, Amistar Top, Kemazed and Occidor resulted in the lowest levels of stemend rot, followed by kocide 2000 and Antracol, while Copprotech was the least effective fungicides. These results could be interpreting in light the findings of (Muirhead et al, 1982) who found that mature unripe Fuerte avocado fruit from 2 sources were dipped in carbendazim (1 $\mathrm{g} /$ litre) controlled stem-end rot, the percentages of diseasefree fruit from the 2 sources were increased from 1 to $90 \%$.

This study is thought to be the first in this attitude in Egypt. This confirms that stemend rot and failure grafting followed by dieback of avocado can be initiated by fungus causing branch dieback and stresses the importance of controlling branch dieback.

Table 7: Efficiency of some fungicides against of $L$. theobromae on Hass cultivar during grafting and stem-end rot.

\begin{tabular}{|l|c|c|c|c|c|c|c|c|c|c|c|c|}
\hline \multirow{2}{*}{ Treatments } & \multicolumn{7}{|c|}{2015} & \multicolumn{6}{c|}{2016} \\
\cline { 2 - 14 } & $\begin{array}{c}\text { \%failure grafted } \\
\text { seedlings }\end{array}$ & \multicolumn{2}{|c|}{$\%$ stem-end rot } & \multicolumn{2}{c|}{$\begin{array}{c}\text { \%failure grafted } \\
\text { seedlings }\end{array}$} & \multicolumn{2}{c|}{$\%$ stem-end rot } \\
\cline { 2 - 14 } & $\mathrm{C}^{*}$ & $\mathrm{~T}^{*}$ & $\mathrm{E}^{*}$ & $\mathrm{C}^{* *}$ & $\mathrm{~T}^{* *}$ & $\mathrm{E}^{* *}$ & $\mathrm{C}^{*}$ & $\mathrm{~T}^{*}$ & $\mathrm{E}^{*}$ & $\mathrm{C}^{* *}$ & $\mathrm{~T}^{* *}$ & $\mathrm{E}^{* *}$ \\
\hline Kemazed & 20 & 1 & 95 & 20 & 2 & 90 & 20 & 1 & 95 & 20 & 1 & 90 \\
\hline Kocide20 00 & 20 & 3 & 85 & 20 & 3 & 85 & 20 & 2 & 90 & 20 & 3 & 85 \\
\hline Amistar Top & 20 & 0 & 100 & 20 & 1 & 95 & 20 & 0 & 100 & 20 & 1 & 95 \\
\hline Topsin M70 & 20 & 1 & 95 & 20 & 0 & 100 & 20 & 0 & 100 & 20 & 1 & 95 \\
\hline Antracol & 20 & 2 & 90 & 20 & 3 & 85 & 20 & 2 & 90 & 20 & 3 & 85 \\
\hline Occidor & 20 & 1 & 95 & 20 & 2 & 90 & 20 & 2 & 90 & 20 & 3 & 85 \\
\hline Copprotech & 20 & 2 & 90 & 20 & 4 & 80 & 20 & 2 & 90 & 20 & 3 & 85 \\
\hline
\end{tabular}

$\mathrm{C}^{*}=$ (control): number of failure untreated scions. $\mathrm{T}^{*}=$ number of failure treated scions with fungicides. $E^{*}=\%$ efficiency.

$\mathrm{C}^{* *}=$ (control):number of inoculated and untreated fruit. $\mathrm{T}^{* *}=$ number of inoculated and treated fruit with fungicides. $E^{* *}=\%$ efficiency. 


\section{REFERENCES}

Aaron, J. P., R.C. Ploetz and P. F. Harmon (2006). Florida Plant Disease Management Guide: Avocado (Persea americana) .1:10.

Abd El Aziz, A.S., Sahar M. El-Baz and M.A. Kamhawy (2010). Mango die back disease in Egypt and its control. Egypt Journal of Appl. Sci., 25 (10A).

Abo Rehab, M.E.A., A.K.M. Korra, M.A.M. Kamhawy and K.Y.A Youssef (2013). Fungal species associated with graft union on grapevine, its Impact on graft failure process and attempted solutions in Egypt. International Journal of Agriculture and Forestry, 3(2): 52-59.

Aroca, A., R. Raposo, D. Gramaje, J. Armengol, S. Martos and J. Luque (2008). First report of Lasiodiplodia theobromae on rootstocks mother grapevines in Spain. Plant Disease, 92:832.

Barakat, M.F., K.A. Abada and K.A. Korra (1990). Factors affecting pathogenicity of peach die-back fungi and their control. Proceedings of the Sixth Congress of Phytopathology, Cairo, March, 1990, 593 -603 .

Cardoso, J. E., C. M. Maia and M. N. G. Pessoa (2002). Occurrence of Pestalotiopsis psidii and Lasiodiplodia theobromae causing stem-end rot of guava plants in the State of Ceara, Brazil. Fitopatol. Bras, 27: 320.

Darvas, J. M. and J. M. Kotze (1981). Postharvest diseases of avocados. Yearbook, South African Avocado Growers' Association, 4: 63-66.

Davis, R. M., C. J. Farrald and D. Davila (1987). Botryodiplodia trunk lesions in Texas citrus. Plant Disease, 71: 848-849.

Elosaily, A. H. (2015). A comparative pharmacognostical study of certain avocado (Persea Americana Mill.) cultivars grown in Egypt. M. Sc.Thesis ;Fac. Pharmacy Cairo Univ., Egypt.

English, H., J. R. Davis and J. E. DeVay (1966). Dothiorella canker, a new disease of almond trees in California . Phytopathology, 56:146.

Faber, B., A. Eskalen and G. Bender (2008). UC IPM Pest Management Guidelines: Avocado, UC ANR Publ. 3436. Oakland, CA.

FAO. (2013). Food and Agricultural Organization.California Avocado Commission. 2010-2011. unprecedented performance: Progress towards sustainable value. Calif. Avocado Comm. Annu. Rep. 12, Mauchly, Irvine, CA. http://faostat.fao.org.

Fourie, P. H. and F. Halleen (2004). Occurrence of grapevine trunk disease pathogens in rootstock mother plants in South Africa. Australian Plant Pathology, 33: 313-315.

Freire, F. C. O., J. E. Cardoso, A. A. dos Santos and F. M. P. Viana (2002). Diseases of cashew nut plants (Anacardium occidentale L.) in Brazil. Crop Prot., 21:489-494.

Gaser, A. S. A. (2007). Impact of some rootstocks on performance of superior grape cultivar. Journal of Agriculture Science Mansoura Univ., 32 (11) : 91559183.

Halma, F. F. and G. A. Zentmyer (1953). Relative susceptibility of Guatemalan and Mexican avocado varieties to Dothiorella canker.Calif. Avocado Soc. Yearb, 38:156-158.

Hartill, W. F. T. and K. R. Everett (2002). Inoculum sources and infection pathways of pathogens causing stem-end rot of 'Hass' avocados. New Zealand Journal Crop Hortic. Sci., 30:249-260.

Horne, W. T. (1932). Pests and diseaseslatest developments in avocado disease control. Calif. Avocado Assoc. Yearb. 17:33-37.

Johnson, G.I., A.W. Cooke, A.J. Mead and I. A. Wells (1991). Stem rot pathogens of fruit are endophytes. Australian Plant Pathology Society 8 th Conference, Sydney, 34.

McDonald, V. and A. Eskalen (2011). Botryosphaeriaceae species associated 
with avocado branch cankers in California. Plant Disease, 95:1465-1473.

Menge, J. A. and R. C. Ploetz (2003). Diseases of avocado. Diseases of Tropical Fruit Crops, 35-71.

Michailides, T. J. (1991). Pathogenicity, distribution, sources of inoculum, and infection courts of Botryosphaeria dothideaon pistachio. Phytopathology, 81:566-573.

Milad, Y. (1936). Avocado culture in Egypt .California Avocado Association Yearbook, 21: 76-78.

Muirhead, I. F., R. D. Fitzell, R. D. Davis and R. A. Peterson (1982). Post-harvest control of anthracnose and stem-end rots of Fuerte avocados with prochloraz and other fungicides. Australian Journal of Experimental Agriculture and Animal Husbandry, 22: 441-446.

Ploetz, R. C., D. Benscher, A. Vazquez, A. Colls, J. Nagel and B. Schaffer (1996). A re-examination of mango decline in Florida. Plant Disease, 80: 664-668.

Rowell, A. W. G. (1983). Post-harvest disease control in avocados using prochloraz. South Africa Avocado Growers' Assn. Yearb, 6:19.

Smith, L. A., E. K. Dann, J. Leonardi, J. R. Dean and A. W. Cooke (2012). Exploring non-traditional products for management of postharvest anthracnose and stemend rot in avocado. elizabeth.dann@deedi.qld.gov.au.
Snedecor, G.W. and W.G. Cochran (1984). Statistical Methods. Iowa State University Press, 9th Ed., 503pp.

Sutton, B. C. (1980). The Coelomycetes. Commonw. Mycolog. Inst., Kew, Surrey, England.

Swart, W. J., R. M. Oelofse and M.T. Labuschagne (2003). Susceptibility of South African cactus pear varieties to four fungi commonly associated with disease symptoms. J. PACD, pp. 86-97.

Tovar, P.J.M., J.A. Mora, A. C. Nava, D. O. Téliz, G. P. Valdovinos, A. M. Villegas and Y. G. Leyva (2013). Control of Lasiodiplodia theobromae, the causal agent of dieback of Mamey sapote [ Pouteria sapota (Jacq.) H. E. Moore and Stearn] grafts in Mexico.Rev. Fitotec. Mex. Vol. 36 (3): $233-238$.

Twizeyimana, M., H. Förster, V. McDonald, D. H. Wang, J. E. Adaskaveg and A. Eskalen (2013). Identification and pathogenicity of fungal pathogens associated with stem-end rot of avocado in California. Plant Disease, 97:15801584.

Urbez -Torres, J. R., G. M. Leavitt, T. M. Voegel and W. D. Gubler (2006). Identification and distribution of Botryosphaeriaspp. associated with grapevine cankers in California. Plant Disease, 90:1490 -1503. 
مكافحة لاثيوديبلوديا ثيويرومى على الأفوكادو فى مصر

محمود عواد رضوان ، مبروثك سيد سيد حسن

معهد بحوث أمراض النباتات بالجيزة - مصر

الملخص العربى

أجريت هذة الدراسة فى موسمى 2015-2016 لتعريف الفطريات المسبية لموت الأطارف، فنثل عملية

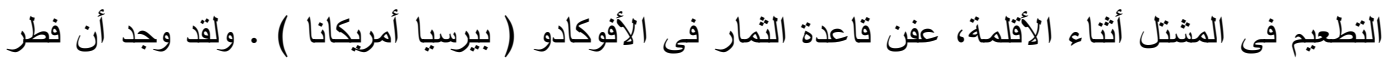

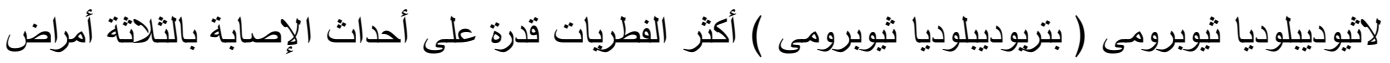

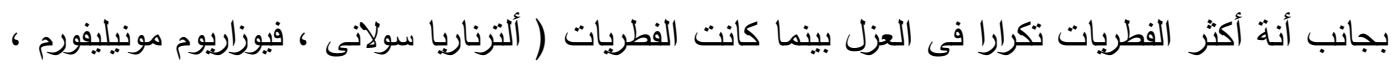

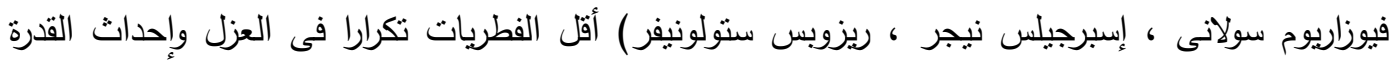

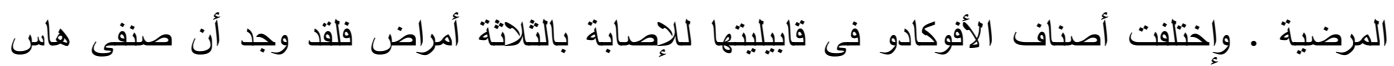
وفيورت أعلى الأصناف قابلية للأصابة يليهما إيتينجر وديوك وريد بينما بيكون وبينكرتون أقل الأصناف قابلية للإصابة بمرضى موت الأطارف وعفن قاعدة الثمار ـ وكان هاس وفيورت أكثر قابلية للإصابة بفتشل ودئل

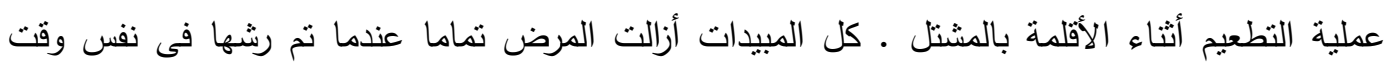
العدوى بفطرلاثيوديبلوديا ثيوبرومى المسبب لمرض موت الأطارف يليها الرش قبل العدوى بالفطر بسبعة

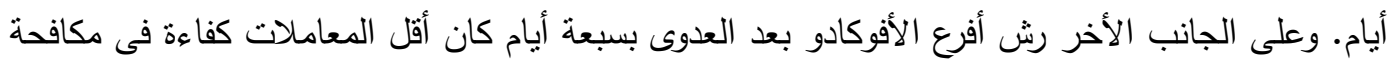

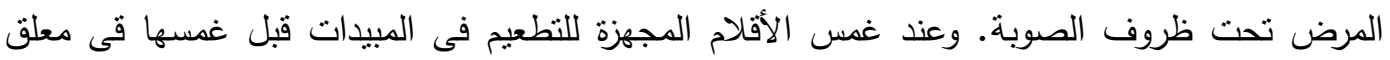

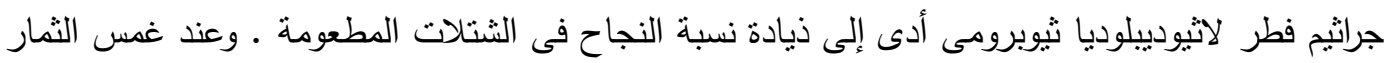

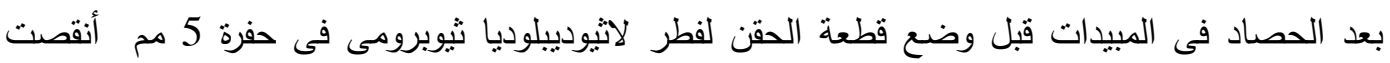

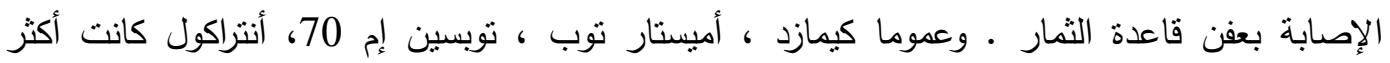

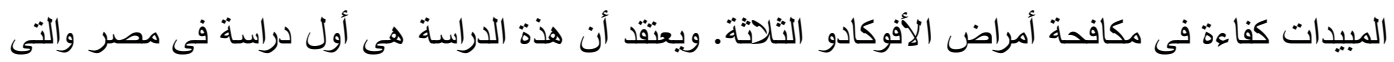

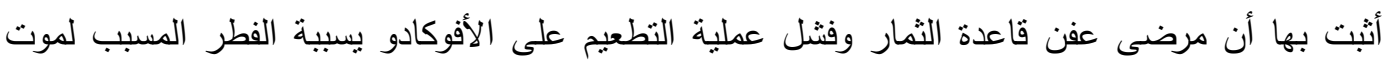

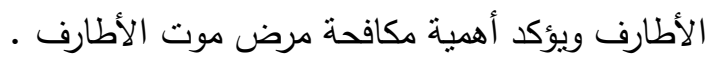

